Research Article

\title{
Principal Leadership Model
}

\author{
Hari Siswanto *, Aslamiah, Darmiati \\ Master Program of Education Management, Universitas Lambung Mangkurat, Banjarmasin 70123, Indone- \\ sia
}

Article history:

Submission September 2020

Revised November 2020

Accepted November 2020

*Corresponding author:

E-mail: hari.siswanto@gmail.com

\begin{abstract}
For every school to achieve its vision, mission, and educational goals, a leader is someone who can direct it to achieve it. This study aimed to describe and analyze in-depth the leadership models and leadership strategies of principals applied by principals at SMPN 4 Katingan Hilir and SMPN 5 Katingan Hilir. This research approach uses a qualitative multisite type. The leadership model at SMPN 4 Katingan Hilir is the principal of communicating, guiding, and setting an example. The school principal carries out the vision and mission and the joint work program strategy and builds trust and is involved in transparent decision making. The leadership approach pattern of group dynamics and leadership models are applied participatory models with a democratic leadership style. The leadership model at SMPN 5 Katingan Hilir communicates, guides, directs, and consistently implements joint work programs and supervisors, initiators in realizing the school's vision and mission per the goals to be achieved. Principals build trust, openness, deliberation, and transparency, achievement, and real work. The principal's strategy is a good role model and an opportunity to innovate in sustainable professional development. A situational leadership approach is based on group dynamics, transformationalist leadership models, and democratic (participatory) leadership styles. Researchers suggest that the principal provides moral guidance, direction, and motivation to improve the school's quality and quality positively. For teachers is to continue to develop themselves. For the institution, they are, namely, maximizing the implementation of each educational program per the vision and mission, and objectives of the school to improve the quality and quality of the school.
\end{abstract}

Keywords: Leadership model, leadership strategy, principal

\section{Introduction}

Schools are educational institutions that are responsible for realizing the functions and goals of national education. It is because school and environmental factors are independently associated with academic progress (Catsambis \& Beveridge, 2001), which supports the functions and goals of national education. Schools as institutions are allowed to organize in the coordination process to achieve educational goals (Musidani, Mardhatillah, \& Khausar, 2019). One of the educational goals' achievements depends on the principal's skills and leadership policies: the education leader in an academic unit. Citing to the Regulation of the Minister of Education and Culture Number 6 2018 concerning the assignment of teachers as school principals in Article 1, the principal is a teacher given the task of leading and managing an education unit. Meanwhile, Article 15 explains the school principals' workload in carrying out managerial, entrepreneurial, and supervisory tasks for teachers and education personnel.

The principal is the one who manages all activities in the school (Khan et al., 2014). Great 
teachers need quality leadership in managing schools (Manan, 2014; Poernamawijaya et al., 2018). As the person most responsible for the school, whether it is management, administration, or implementation of teaching policies and practices (Ramaiah, 2003; OECD, 2005; Pashiardis \& Brauckmann, 2008), principals should have foresight, be pro-active, and dare to make changes (Mat Zin, 1996). It is because leaders in educational institutions and teachers must face internal and external pressure to change their teaching practices so that students can achieve high standards (Hallam \& Hausman, 2009). Efficient school principals allow schools to manage their human resources more effectively (Tschannen-Moran, 2004). As an effective school principal, they must encourage all school members' teamwork, make decisions, and then make constructive knowledge and a learning community where they can develop (Marks \& Printy, 2003). When the results of the teacher's hard work and the learning outcomes are rewarded, it can be introduced and promoted further (Bruggencate et al., 2012; Jensen, 2010).

The role of leaders in this educational institution, according to Wahab (2011), is to facilitate the achievement of goals for the common good. Education leadership contains two definitions. First, in education, leadership implies where and in what kind of area the leadership takes place and explains the traits or characteristics the leader must-have. Meanwhile, leadership is universal, which can be interpreted as applicable in all lines and various human activity fields. This leadership can be seen as a power relationship between the leader and his followers (Northouse, 2009). Kouzes and Posner describe four critical characteristics of leadership: honesty, futuristic thinking, inspiration, and competence (Kouzes \& Posner, 2003). Effective leadership is the best solution between actions, context, and needs (Goldsmith, 2003), although the environment also affects how effective a leader is in certain situations (Horner, 1997). Meanwhile, leadership style is also influenced by the cultural and state context (Arvey et al., 2015; Jing \& Avery, 2016).
In an organization, according to Aslamiah (2015), leaders and subordinates are needed to achieve organizational goals together, and leadership is a process. This influence allows leaders to make their subordinates willing to do well in what should be done. Leadership focuses on achieving common goals to be achieved, namely, organizational goals. Another opinion by Aprilana, Kristiawan, \& Hafulyon (2017) shows that leadership is essential in running an organization. In organizations, a general leader's behavior is needed, namely orientation to duties/obligations and subordinates' orientation or paying attention to duties/obligations and subordinates (Gill, 2006). To obtain targeted results for the organization, a leader-subordinate relationship is needed (Bass, 1990; Saleem, 2015) so that a good leader is one who helps his subordinates to work efficiently and effectively without feeling dissatisfied (Khuwaja et al., 2020).

Wahjosumidjo (2010) states that "the principal's leadership quality is significant as the key to school success." The quality of school heads is one of the fundamental factors that significantly influence the quality of the teaching and learning method in the education system (Bitterova, Haskova, \& Pisonova, 2014). In its implementation, a good education is carried out by quality education components, especially principals as educators, managers, administrators, supervisors, leaders, and innovators in their work. To achieve quality education is very much dependent on the quality of the principal's leadership.

At the school level, the leader is the principal key figure in encouraging school development and progress. The principal not only increases responsibility and authority in-school programs, curriculum, and personnel decisions but also has the responsibility to increase accountability for the success of students and their programs. The principal must be good at leading groups and delegating tasks and authorities (Mahardhani, 2016). For example, principals of junior high schools in Botswana have different views regarding school management and communication between the community and the school regarding student learning outcomes (Chapman \& Burchfield, 1994), 
which determine how they become important figures that they can develop and advance the school.

The principal is the determinant of the policy direction towards quality schools and education. The principal's success in leading will be seen from what he has done for the institution so that the implication can be felt. Namely, the teacher can carry out tasks with a full sense of responsibility, and the set educational goals can be achieved. Meanwhile, the criteria for successful school leadership which are the key to success for school quality are: (1) having the ability to manage the institution they lead; (2) can anticipate changes; (3) reliable in correcting shortcomings and weaknesses; and (4) able to bring the institution to its stated objectives. According to Rusmawati (2013), leadership success stems from a person's character traits and is mostly defined by particular personality traits such as self-esteem, initiative, intelligence, fluency, creativity, physical characteristics. The leader is sufficient if the leader has a cross-trajectory character (Rusmawati, 2013).

The principal's role and function are a strategy for developing the school through the quality of education and motivating subordinates to achieve the school's vision and mission. Purnama (2016) argues that the school's success in achieving the school's vision, mission, and goals is strongly influenced by the competence and capacity of the principal in managing human resources as operational executors of tasks at school. The principal is a manager who has a strategic role in determining its human resource management mechanism.

The leadership style and model of the principal are indispensable in carrying out its duties and functions. This leadership model and style are the underlying values in leading school institutions. Some examples of principals' leadership styles and models are democratic, autocratic, and Laissez-faire leadership models (Aruzie et al., 2018). Other leadership types include transactional and transformational (Brata et al., 2017). These two leadership styles should not be seen as opposing approaches but complement each other (Robbins, 2008). With various leadership styles and models, the way to lead a school can vary from one school to another, depending on the principal's views in carrying out his duties and functions.

This research took place at SMPN 4 Katingan Hilir and SMPN 5 Katingan Hilir because these locations were motivated by several specific considerations regarding the principal leadership model. Both schools were per the topics in this study. The purposes of this study were to describe in-depth and analyze in detail the following: (1) principal leadership models including the formulation of a vision and mission, management of education in schools; and (2) leadership strategies include strategies that are implemented and evaluated of the leadership of school principals.

\section{Material and Methods}

This research is about the principal's leadership model with a qualitative approach with a multisite study design. The researchers used data collection techniques using in-depth interviews, role observation, and documentation study at SMPN 4 Katingan Hilir and SMPN 5 Katingan Hilir. A purposive technique selected research informants by selecting people who are considered to know the problem's focus. In this study, data sources were deputy principals, teachers, facilitators, school committees, and administration.

The data that has been collected is checked for the validity of the data according to Lincoln and Guba (1985), namely: (1) credibility by continuous observation, peer discussion, and member check; (2) transferability by providing a detailed description of the research findings; (3) dependability by asking the auditor to audit it; and (4) confirmability, namely the assessment of research results by experts.

This study's data analysis technique is divided into on-site data analysis and off-site data analysis. (1) data analysis on the website is data analysis at schools used as research sites, and (2) cross-site data analysis is the integration of findings generated from several sites.

\section{Results and Discussion Leadership model}

The leadership model includes the leadership model applied at SMPN 4 Katingan Hilir and SMPN 5 Katingan Hilir and the principal's efforts in determining the vision and mission. 
The findings regarding the leadership model of the principal of SMPN 4 Katingan Hilir in directing subordinates is that they always provide direction and guidance for their subordinates. The principal is also firm with the imposition of disciplinary sanctions. The principal provides a good role model and is polite to everyone he meets. In line with Iskandar's (2013) opinion, the principal must instill, advance, and enhance mental, moral, physical, and artistic values in his subordinates by showing persuasive and exemplary attitudes. The results of research by Rusmawati (2013) that school principals as motivators must motivate their subordinates, which are developed to improve work performance and existing educational job satisfaction that will ultimately improve the work discipline of educational personnel.

Leadership can be seen as a trait inherent in a leader, namely the ability to direct, motivate, provide comfort, service, loyalty, respect, guide, direct, communicate, interact, build relationships, become a father figure, and have a broad knowledge. Islam implies it as the characteristics of shiddiq, amanah, tabligh, and fathanah that can influence and hold the capacity to influence a group towards achieving specific goals (Said, 2018). In other words, the leader's nature or character is based on core values such as integrity, trust, truth, and selfesteem, which influence the vision, ethics, and behavior (Sankar, 2003). Therefore, it can be seen that individual personality traits are essential concerning leadership effectiveness (Parr, Lanza, \& Bernthal, 2016).

As for determining the school's vision and mission, namely by involving all school personnel, the achievement of the vision and mission and strategies can be carried out well, namely by involving all stakeholders and committees to implement the vision and mission. The school principal also manages BOS funds well, is cooperative, responsible, firm, and committed to what is said.

The principal is fair and transparent to every school member, in all activities and management, both in finances, school programs, or decision making. Be fair and firm, get equal rights without any social gaps in it. It is per the opinion of Fritz (1995) that vision is a vital design serving schools to reorganize in ways that guarantee their continued viability, legitimacy, and value as core institutions in our society.

To achieve the goals of educational organizations that have been set together, leaders and groups depend on each other so that the principal's leadership is an activity that contributes to the success of the educational institutions they lead. This opinion was confirmed by Ekosiswoyo (2007) that the principal, through leadership, should empower the potential of teachers in the learning process. Have a clear time agenda for completing tasks, establish healthy interpersonal relationships, act reasonably, effectively, efficiently, responsibly, and be accountable and work through a management team that involves all school components.

The findings regarding the model of the principal at SMPN 5 Katingan Hilir are that the principal communicates, guides, and directs all school personnel appropriately, cooperates, and is open to everything, is responsible, agreed, and consistently implements joint work programs of all school members. As a supervisor, the principal controls, guides, directs, supports, protects, advises, motivates, is entrepreneurial, and, as an initiator, has a role in realizing the school's vision and mission by the goals to be achieved through educational programs in schools. This finding is per the opinion of Ginting and Haryati (2012) that the principal as a leader has the potential to create a vision and mission and translate reality and play a role as a central force in driving school life and understanding the duties and functions of developing the quality of education.

In planning the vision and mission of the principal, builds the trust of school members and stakeholders with openness, deliberation and transparency, achievement and real work, honesty, and commitment to advancing the school, carrying out duties with full responsibility and high awareness, and being a good role model-management through activities to divide tasks according to competence. The principal directs and assists and assists provide freedom for self-exploration and development potential. It is per the opinion of Wahyudin 
(2018) that school head leadership is one of the determining factors that can move all school resources to be able to realize the vision, mission and goals, and objectives of the school. A program implemented in a planned and programmed manner is fair and transparent by involving all personnel.

In line with Saleh and Aini's (2014) research that the leadership of the MTsN Model Samarinda school principal in improving teacher work performance appears in various leadership roles in carrying out their duties and functions through efforts to foster togetherness, conducive guidance and various roles in realizing common goals and creating a fun working atmosphere. The findings regarding the leadership model on these two sites are in line with the opinion of Nasution (2015), which states that the indicators of a practical principal are: having a clear vision and being able to encourage all school members to make it happen; have high expectations of achievement; program and provide positive and constructive feedback to improve learning and encourage efficient use of time, utilize various learning resources, monitor student progress and carry out evaluation and continuous improvement.

Table 1. Principal leadership model

\begin{tabular}{|c|c|c|c|}
\hline \multirow[b]{2}{*}{ Focus } & \multicolumn{3}{|c|}{ Findings } \\
\hline & $\begin{array}{c}\text { SMPN } 4 \text { Katingan } \\
\text { Hilir }\end{array}$ & SMPN 5 Katingan Hilir & Conclusion \\
\hline $\begin{array}{l}\text { Vision, } \\
\text { mission, } \\
\text { and goals of } \\
\text { the school }\end{array}$ & $\begin{array}{l}\text { Directing subordinates } \\
\text { in the vision and } \\
\text { mission through the } \\
\text { discipline of all school } \\
\text { members }\end{array}$ & $\begin{array}{l}\text { Directing subordinates in the } \\
\text { vision and mission through } \\
\text { educational programs in } \\
\text { schools }\end{array}$ & $\begin{array}{l}\text { Actions in realizing } \\
\text { the vision and } \\
\text { mission provide } \\
\text { direction and school } \\
\text { goals in the long } \\
\text { term } \\
\text { Commitment to } \\
\text { educational goals in } \\
\text { schools }\end{array}$ \\
\hline $\begin{array}{l}\text { Vision and } \\
\text { mission } \\
\text { determinati } \\
\text { on }\end{array}$ & $\begin{array}{l}\text { Involving educational } \\
\text { stakeholders in the } \\
\text { determination through } \\
\text { deliberation activities }\end{array}$ & $\begin{array}{l}\text { The agreement in fulfilling } \\
\text { the vision and mission is the } \\
\text { responsibility of the } \\
\text { stakeholders }\end{array}$ & $\begin{array}{l}\text { Actions in realizing } \\
\text { the vision and } \\
\text { mission provide } \\
\text { direction and school } \\
\text { goals in the long } \\
\text { term }\end{array}$ \\
\hline $\begin{array}{l}\text { Commitmen } \\
\text { t to } \\
\text { educational } \\
\text { goals in } \\
\text { schools }\end{array}$ & $\begin{array}{l}\text { Participatory decision- } \\
\text { making by all } \\
\text { stakeholders } \\
\text { prioritizes } \\
\text { commitment } \\
\text { discipline }\end{array}$ & $\begin{array}{l}\text { Transparency in various } \\
\text { aspects, efforts to increase } \\
\text { trust, and deliberation and } \\
\text { joint commitment to } \\
\text { advancing schools }\end{array}$ & $\begin{array}{l}\text { Commitment to } \\
\text { educational goals in } \\
\text { human education } \\
\text { resources } \\
\text { determines the } \\
\text { performance of an } \\
\text { educational } \\
\text { institution }\end{array}$ \\
\hline $\begin{array}{l}\text { Teacher } \\
\text { innovation }\end{array}$ & $\begin{array}{l}\text { Freedom to explore } \\
\text { one's abilities is } \\
\text { accompanied by } \\
\text { responsibility and good } \\
\text { cooperation }\end{array}$ & $\begin{array}{l}\text { Teacher empowerment and } \\
\text { competency adjustment in } \\
\text { assignments, exploration and } \\
\text { individual initiative and } \\
\text { potential development }\end{array}$ & $\begin{array}{l}\text { A relevant role in } \\
\text { improving the } \\
\text { quality of education } \\
\text { with the primary } \\
\text { objective of }\end{array}$ \\
\hline
\end{tabular}




\begin{tabular}{ccc}
\hline \multirow{2}{*}{ Focus } & \multicolumn{3}{c}{ Findings } \\
\cline { 2 - 3 } & SMPN 4 Katingan & \multicolumn{1}{c}{ Conclusion } \\
\hline & SMPN 5 Katingan Hilir & $\begin{array}{l}\text { developing the } \\
\text { potential of human } \\
\text { resources }\end{array}$ \\
\hline
\end{tabular}

\section{Leadership strategy}

The leadership strategy applied is a strategy applied in leading school members, including good patterns, communication links, and leadership evaluation, through increasing teacher competence. Another opinion by Suriansyah and Aslamiah (2015) regards principal leadership strategies that can shape character through the communication of philosophy, vision, clear mission, exemplary, discipline and instructional leadership, quality leadership, and empowerment of teachers and education personnel. Findings regarding the leadership strategy of the principal at SMPN 4 Katingan Hilir is the exemplary attitude displayed by the principal in the continuity and smoothness of every process related to his leadership.

The results of Wening and Santosa's (2020) The leadership strategy needed in the digital era 4.0 by improving human resources in the field of technology and informatics in terms of facilities and infrastructure, openness, and development to deal with things that will happen in the 4.0 era, reactions are carried out with quickly through the 4C formula: critical thinking, creativity, communication, and collaboration. Evaluation through motivation and encouragement to all teachers and staff and their students maximize individual potential related to reward giving and related to the supervision carried out by the principal of all teachers, which is carried out regularly at least two times in one semester. In line with the results of Muslimah research (2020), the principal provides periodic supervision to teachers in compiling a complete lesson plan per the demands of the process standards and assessment standards, which are part of the national education standard. Through this periodic supervision, it can improve teacher competence in preparing RPP K13. So, it can be reasoned that the leadership of the principal of SMPN 4 Katingan Hilir is a group dynamics approach, participatory leadership model, and democratic leadership style.

The leadership model applied at the first site is a participatory leadership model. It is in line with Yoto's (2011) opinion that a participatory leadership style is characterized by low task behavior patterns and high tolerance behavior patterns. Principals pay attention to teachers' and employees' welfare and strive to develop their potential to achieve maximum personal growth and professional growth. The findings regarding the leadership strategy of the principal of SMPN 5 Katingan Hilir are to increase the role and function through a good example in terms of attitudes and speech as well as behavior and mindset that are good in leadership, discipline, working well, and protecting all teachers and student participants. Similar to the research results by Maimun (2017), the supporting factor for the success of school principals in achieving religious-cultural goals is the commemoration of holidays by respecting differences, togetherness in all programs and activities, and the principal protects the differences that exist in schools and open management.

Table 2. Principal leadership strategy

\begin{tabular}{|c|c|c|c|}
\hline \multirow[b]{2}{*}{ Focus } & \multicolumn{3}{|c|}{ Findings } \\
\hline & $\begin{array}{c}\text { SMPN } 4 \text { Katingan } \\
\text { Hilir }\end{array}$ & SMPN 5 Katingan Hilir & Conclusion \\
\hline $\begin{array}{l}\text { Exemplar } \\
\text { y patterns }\end{array}$ & $\begin{array}{l}\text { Exemplary by giving } \\
\text { full responsibility } \\
\text { together, the discipline } \\
\text { of all school members, }\end{array}$ & $\begin{array}{l}\text { Exemplary applied to protect } \\
\text { all school members and } \\
\text { efforts to minimize cases that } \\
\text { will occur }\end{array}$ & $\begin{array}{lr}\text { Exemplary } & \\
\text { application } & \text { can } \\
\text { affect } & \text { teacher } \\
\text { satisfaction, which }\end{array}$ \\
\hline
\end{tabular}




\begin{tabular}{|c|c|c|c|}
\hline \multirow{3}{*}{ Focus } & \multicolumn{3}{|c|}{ Findings } \\
\hline & $\begin{array}{c}\text { SMPN } 4 \text { Katingan } \\
\text { Hilir }\end{array}$ & SMPN 5 Katingan Hilir & Conclusion \\
\hline & $\begin{array}{l}\text { and commitment to } \\
\text { advancing education }\end{array}$ & & $\begin{array}{l}\text { has an impact on } \\
\text { improving work } \\
\text { performance }\end{array}$ \\
\hline $\begin{array}{l}\text { Communi } \\
\text { cation } \\
\text { lines }\end{array}$ & $\begin{array}{l}\text { Efforts at the right } \\
\text { communication } \\
\text { Motivation, support, } \\
\text { and motivation to } \\
\text { work is in the form of } \\
\text { rewards so that } \\
\text { teachers can improve } \\
\text { their performance. }\end{array}$ & $\begin{array}{l}\text { Good communication } \\
\text { patterns, motivation and } \\
\text { support, and appreciation } \\
\text { through achievement } \\
\text { management are given to } \\
\text { teachers who show } \\
\text { performance and business } \\
\text { results. }\end{array}$ & $\begin{array}{l}\text { Motivation is an } \\
\text { effort to improve } \\
\text { and encourage } \\
\text { teacher } \\
\text { performance. } \\
\text { Communication } \\
\text { patterns are } \\
\text { cooperation and } \\
\text { good relations for } \\
\text { every school } \\
\text { member. }\end{array}$ \\
\hline $\begin{array}{l}\text { Increased } \\
\text { teacher } \\
\text { competen } \\
\text { ce }\end{array}$ & $\begin{array}{l}\text { Improving teacher } \\
\text { quality and } \\
\text { competence through } \\
\text { training and mentoring } \\
\text { activities for learning }\end{array}$ & $\begin{array}{lr}\text { Increasing } & \text { teacher } \\
\text { professionalism through } \\
\text { training activities and } \\
\text { developing } & \text { teacher } \\
\text { resources } & \end{array}$ & $\begin{array}{l}\text { Coaching and } \\
\text { developing teacher } \\
\text { resources in quality } \\
\text { improvement } \\
\text { through planned } \\
\text { activities }\end{array}$ \\
\hline $\begin{array}{l}\text { Supervisi } \\
\text { on }\end{array}$ & $\begin{array}{l}\text { Periodic supervision } \\
\text { and efforts to improve } \\
\text { the quality of } \\
\text { education through } \\
\text { learning }\end{array}$ & 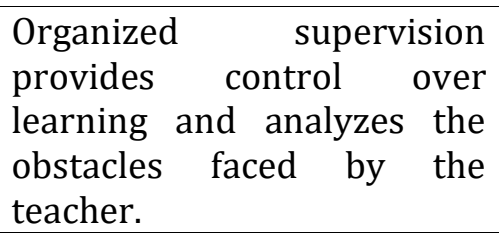 & $\begin{array}{l}\text { Supervision is a } \\
\text { control to improve } \\
\text { performance and } \\
\text { control the goals set. }\end{array}$ \\
\hline
\end{tabular}

They were related to evaluating the principal's duties through achievement management and supervision of scheduled learning devices. The principal supervises the learning device and is carried out per semester once a semester. In line with the research results conducted by Bahiroh and Hariyati (2020), the implementation of supervision was carried out by the school principal at SMA Darul Ulum 1, Unggulan BPPT Jombang, was carried out on a scheduled and unscheduled basis. Scheduled supervision is in odd semesters with pre-supervision, observation, and post-supervision stages. Meanwhile, unscheduled supervision is carried out in the even semester to monitor the results of scheduled supervision.

It was concluded that the leadership of SMPN 5 Katingan Hilir has a leadership approach based on group dynamics. The transformationalist leadership model and leadership style are democratic (participative).
Findings on-site 2 regards transformationalist leadership models. Per Ambarwati's (2003) opinion, transformationalist leadership behaves more advanced and motivates followers to identify the vision of leadership and sacrifice their self-interest for the benefit of the group or organization. Another opinion by Kuswaeri (2016) that transformational leadership is leadership that changes energy resources and sites to achieve goals. A democratic (participatory) leadership style, according to Setiawan (2017), where leaders involve making decisions that allow others to influence some of the leader's decisions. Subordinates participate in goal setting and problem-solving.

The findings on both sites regarding leadership styles are in line with Wibowo, Saleh, \& Effendi (2020), which states that the Banjarmasin Vocational School principal adopted a participatory leadership style empowering educator. The evidence showed all school members' involvement in school programs. The principal 
involves all teaching staff and all administrative staff in program planning to joint decisionmaking in managing school programs, information disclosure, communication, consultation, and delegation of tasks.

The efforts of the two sites in improving teacher professionalism through education and training activities are in line with Kunandar's (2009) opinion that school principals can implement strategies: (1) listening; (2) clarifying; (3) encouraging (encouraging); (4) presenting; (5) solving problems; (6) negotiation; (7) demonstrating (8) directing; (9) standardize (standardization); and (10) provide reinforcing.

The group dynamics approach at both sites is a leadership that provides direction to subordinates for achieving goals and maintaining integrity. It is per the results of research by Idris (2019) that a leadership approach based on group dynamics significantly affects leaders in using a style based on two dimensions. Namely, a style-oriented towards cooperative relations (supportive) and a style-oriented approach towards the leader's direction only.

\section{Conclusion and Recommendation}

Referring to the formulation of the problem and research objectives, discussion, research findings, data analysis. According to the research outcomes conducted by the author at SMPN 4 Katingan Hilir and SMPN 5 Katingan Hilir about the leadership model of school principals are as follows:

a. Leadership Model

The leadership model of the head of SMPN 4 Katingan Hilir in directing subordinates is always to provide direction and guidance to his subordinates, to be firm with the imposition of sanctions regarding discipline, and to provide good role models and courtesy.

As for determining the school's vision and mission, namely by involving all school personnel, principals are fair and transparent in all activities and management, are fair and firm, and get equal rights without any social gaps.

The leadership model of the principal of SMPN 5 Katingan Hilir, namely the principal communicates, guides, and directs all school personnel appropriately, collaborates, and is open to everything, is responsible, agreed, and consistently implements work programs with all school members. The principal acts as a supervisor who controls, guides, directs, supports, protects, advises, motivates, has good entrepreneurship, and is also an initiator in realizing the school's vision and mission according to its goals.

In determining the principal's vision and mission, it builds the trust of school members and stakeholders with openness, deliberation and transparency, achievement and real work, honesty, and commitment to advancing the school and achieving the vision and mission and goals.

b. Strategy

The leadership strategy of the head of SMPN 4 Katingan Hilir is an exemplary attitude with a good personality and responsibility, discipline and commitment, motivation, and encouragement to all school members by giving praise, rewards, and awards. The principal fosters a spirit of innovation by facilitating teacher development.

Evaluation in this supervision activity is carried out on all teachers regularly at least 2 times during one semester. So, it can be inferred that the leadership of the principal of SMPN 4 Katingan Hilir is a group dynamics approach, participatory leadership model, and democratic leadership style.

The leadership strategy of the head of SMPN 5 Katingan Hilir is a good example, discipline, works well, nurtures, provides motivation and support for teacher ideas and performance, appreciates, gives freedom to think, act, and innovate, as well as explore in teacher development.

It is related to evaluating the principal's duties through achievement management and supervision of scheduled learning devices. It was concluded that the leadership of SMPN 5 Katingan Hilir has a leadership approach based on group dynamics. The transformationalist leadership model and leadership style are democratic (participative).

\section{Acknowledgment}


The author thanked the Education Office in the Katingan Regency, the heads of SMPN 4 Katingan Hilir, and SMPN 5 Katingan Hilir.

\section{References}

Ambarwati, S. D. (2003). Mengelola perubahan organisasional: isu peran kepemimpinan transformasional dan organisasi pembelajaran dalam konteks perubahan. Jurnal Siasat Bisnis, 8(2), 155-176. Retrieved from https://journal.uii.ac.id/index.php/ISB/article/view/101 $2 / 943$

Aprilana, E. R., Kristiawan, M., \& Hafulyon. (2017). Kepemimpinan kepala madrasah dalam mewujudkan pembelajaran efektif di Madrasah Ibtidaiyah Rahmah el Yunusiyyah Diniyyah Puteri Padang Panjang. ELEMENTARY: Islamic Teacher Journal, 4(1), 1-22. doi:10.21043/ELEMTARY.V4i1.1975

Aruzie, R. S., Adjei, A., Mensah, D. A., Nkansah, I., Anorkyewaa, a A., \& Frimpong, B. O. (2018). The Impact Of Leadership Styles On Teaching And Learning Outcomes: A. International Journal of Scientific Research and Management (IJSRM), Vol. 6(12) , 797-825.

Arvey, R., Dhanaraj, C., Javidan, M., \& Zhang, Z. (2015). Are there unique leadership models in Asia? Exploring uncharted territory. The Leadership Quarterly, 26(1), 1-6 doi:10.1016/j.leaqua.2015.01.003.

Aslamiah. (2015). Peningkatan mutu sekolah dasar melalui kepemimpinan transformasional kepala sekolah. Prosiding Seminar Nasional, Prasekolah, Sekolah Dasar, dan Manajemen Pendidikan (PS2DMP). 1, pp. 1-8. Banjarmasin: Program PG-PSD Universitas Lambung Mangkurat. Retrieved from http://eprints.ulm.ac.id/id/eprint/5220

Bahiroh, I., \& Hariyati, N. (2020). Pelaksanaan supervisi akademik oleh kepala sekolah di SMA Darul Ulum 1 Unggulan BPPT Jombang. Jurnal Inspirasi Manajemen, 8(1), 1-10. $\quad$ Retrieved from https://jurnalmahasiswa.unesa.ac.id/index.php/inspirasi -manajemen-pendidikan/article/view/33097/29879

Bass, B. M. (1990). Bass and Stogdill's handbook of leadership: Theory, research and managerial applications. New York, NY: Free Press.

Bitterova, M., Haskova, A., \& Pisonova, M. (2014). School Leader's Competencies in Management Area. Procedia - Social and Behavioral Sciences, 149, 114-118.

Brata, D. P., Imron, A., Sonhadji K.H., A., \& Arifin, I. (2017). Headmaster Leadership Behavior in Strengthening Character. IOSR Journal of Humanities And Social Science (IOSR-JHSS), 22(6), 07-12.

Bruggencate, G., Luyten, H., Scheerens, J., \& Sleegers, P. (2012). Modeling the influence of school leaders on student achievement: how can school leaders make a difference? Educational Administration Quarterly, 48 (4), 699-732.

Catsambis, S., \& Beveridge, A. (2001). Does neighborhood matter? Family, neighborhood, and school influences on eighth-grade mathematics achievement. Sociological Focus, 34(4), 435-457.

Chapman, D. W., \& Burchfield, S. (1994). How headmasters perceive their role: A case study in Botswana. Int Rev Educ., 40, 401-419.

Ekosiswoyo, R. (2007). Kepemimpinan kepala sekolah yang efektif kunci pencapaian kualitas pendidikan. Jurnal Ilmu Pendidikan, 14(2), 76-82. doi:10.17977/jip.v14i2.24

Fritz, R. (1995). Corporate tides: the inescapable laws of organizational structure. San Francisco: Berrett-Koehler Publisher.

Gill, R. (2006). Theory and practice of leadership. London: SAGE Publications.

Ginting, R., \& Haryati, T. (2012). Kepemimpinan dan konteks peningkatan mutu pendidikan. Jurnal Ilmiah CIVICS, 2(2). Retrieved

from journal.upgris.ac.id/index.php/civis/article/viewFIle/45 $5 / 409$

Goldsmith, M. (2003). The many facets of leadership. Upper Saddle River, NJ: Financial Times/Prentice Hal

Hallam, P., \& Hausman, C. (2009). Principal and Teachers Relations: Trust at the Core of School Improvement. In D. A. Saha L.J., International Handbook of Research on Teachers and Teaching. Springer International Handbooks of Education, vol 21. Springer, Boston, MA.

Horner, M. (1997). Leadership theory: Past, present and future. Team Performance Management: An International Journal, 3 (4), 270-287.

Idris, M. (2019). Kepemimpinan kepala sekolah dalam upaya meningkatkan kedisiplinan guru. Ta'dibi: Jurnal Manajemen Pendidikan Islam, 8(1), 44-75. Retrieved from http://ejurnal.stail.ac.id/index.php/tadibi/article/view/123/103

Iskandar, U. (2013). Kepemimpinan kepala sekolah dalam peningkatan kinerja guru. Jurnal Visi Ilmu Pendidikan, 10(1), 1018-1027. doi:10.26418/jvip.v10i1.2061

Jensen, B. (2010). What Teachers Want: Better Teacher Management. Melbourne, Australia: Grattan Institute.

Jing, F., \& Avery, G. (2016). Missing links in understanding the relationship between leadership and organizational performance. International Business \& Economics Research Journal (IBER), 15(3), 107-117 doi:10.19030/iber.v15i3.9675.

Khan, S., Khan, I., ur Rehman, D. R., Khan, F., Khan, R., Rauf, H., \& Yar, B. N. (2014). The Supervisory Role of the Headmaster at the Higher Secondary Level: A Teacher's Perception . Public Policy and Administration Research, 4(9), 51-54. 
Khuwaja, U., Ahmed, K., Abid, G., \& Adeel, A. (2020). Leadership and employee attitudes: The mediating role of perception of organizational politics. Cogent Business \& Management, 7(1), doi: 10.1080/23311975.2020.1720066.

Kouzes, J. M., \& Posner, B. Z. (2003). Credibility: How Leaders Gain and Lose It, Why People Demand it. San Francisco : JosseyBass Publishers.

Kunandar. (2009). Guru profesional implementasi kurikulum tingkat satuan pendidikan (KTSP) dan sukses dalam sertifikasi guru. Jakarta: Rajawali Press.

Kuswaeri, I. (2016). Kepemimpinan transformasionalis kepala sekolah. Tarbawi: Jurnal Keilmuan Manajemen Pendidikan, $2(2)$,

doi:https://www.neliti.com/publication/256472/kepemi mpinan-transformasional-kepala-sekolah

Lincoln, Y. S., \& Guba, E. G. (1985). Naturalistic inquiry. New Delhi: Sage Publication Inc.

Mahardhani, A. J. (2016). Kepemimpinan ideal kepala sekolah. Jurnal Dimensi Pendidikan dan Pembelajaran, 3(2), 1-4 doi:10.24269/dpp.v3i2.82

Maimun. (2017). Keterampilan manajerial kepala sekolah dalam mengembangkan budaya relegius (studi kasus di SMP Negeri 7 Mataram). Jurnal Penelitian Keislaman, 13(2), 178-191. doi:10.20414/jpk.v13i2.787

Manan, M. M. (2014). Leadership Characteristics of Excellent Headmaster . Journal of Education and Practice, 5(23) , 120-123.

Marks, H. M., \& Printy, S. M. (2003). Principal leadership and school performance: an integration of transformational and instructional leadership. Educational Administration Quarterly,39(3), 370-397.

Mat Zin, R. (1996). Kepemimpinan dalam Pengurusan. Kuala Lumpur: Utusan Publications.

Musidani, Mardhatillah, \& Khausar. (2019). Analysis the Role of Headmaster in Applying. Budapest International Research and Critics in Linguistics and Education (BIrLE) Journal,. $2(3), 27-35$

Muslimah. (2020). Upaya peningkatan kompetensi guru dalam menyusun komponen RPP K13 melalui supervisi akademik berkala. Jurnal ABIWARA: Jurnal Nasional Indonesia, 21-30. Retrieved from https:/www.ejurnalnasional.com/index.php/abiwarajurnal/article/view/14/5

Nasution, W. N. (2015). Kepemimpinan pendidikan di sekolah. Jurnal Tarbiyah, 22(1), 66-86. doi:10.30829/tar.v22i1.6

Northouse, P. G. (2009). Introduction to Leadership: Concepts and Practice. Los Angeles: Sage Publications.

OECD. (2005). Teachers Matter: Attracting, Developing and Retaining Effective Teachers. Paris, France: OECD.
Parr, A. D., Lanza, S. T., \& Bernthal, P. (2016). Personality Profiles of Effective Leadership Performance in Assessment Centers. Hum Perform, 29(2) , 143-157.

Pashiardis, P., \& Brauckmann, S. (2008). Evaluation of school principals. In J. L. G. Crow, International Handbook on the Preparation and Development of School Leaders (pp. 1-17). London, UK: Routledge.

Poernamawijaya, L. W., Sulaiman, S., Suriansyah, A., \& Dalle, J. (2018). Contribution on supervision of the supervisor, principals motivation, kindergarten teacher performance to improving the kindergarten quality in West Banjarmasin, Indonesia. European Journal of Alternative Education Studies, $3(2), \quad$ 129-146. doi:10.5281/zenodo.2261031

Purnama, B. J. (2016). Optimalisasi manajemen sumber daya manusia dalam upya peningkatan mutu sekolah. Jurnal Manajemen Pendidikan UNY, 12(2), 27-38. Retrieved from https://www.neliti.com/publications/113839/optimalisa si-manajemen-sumber-daya-manusia-dalam-upayapeningkatan-mutu-sekolah

Ramaiah, A. I. (2003). Kepimpinan pendidikan : Cabaran masa kini. Petaling Jaya: IBS Buku Sdn. Bhd.

Robbins, S. P. (2008). Organizational Behavior (III) . New Jersey: Prentice Hall Inc.

Rusmawati, V. (2013). Peran kepemimpinan kepala sekolah dalam upaya meningkatkan disiplin kerja guru pada SDN 08 Balikpapan. Jurnal Administasi Negara, 395-409. Retrieved from https://ejorunal.ap.fisip-unmul.ac.id

Said, A. (2018). Kepemimpinan kepala sekolah dalam melestarikan budaya mutu sekolah. EVALUASI: Jurnal Manajemen Pendidikan Islam, 2(1), 257-273. doi:10.32478/evaluasi.v2i1.77

Saleem, H. (2015). The impact of leadership styles on job satisfaction and mediating role of perceived organizational politics. Procedia - Social and Behavioral Sciences, 172, 563-569. doi:10.1016/j.sbspro.2015.01.403.

Saleh, K., \& Aini, A. N. (2014). Kepemimpinan kepala sekolah dalam meningkatkan kualitas pendidikan (studi tentang peran kepala MTsN Model Samarinda dalam meningkatkan prestasi kerja guru). Fenomena: Jurnal Penelitian, 6(1), 19-37. doi:10.21093/fj.v6i1.159

Sankar, Y. (2003). Character Not Charisma is the Critical Measure of Leadership Excellence. Journal of Leadership \& Organizational Studies,9(4), 45-55. https://doi.org/10.1177/107179190300900404.

Setiawan, A. (2017). Pengaruh gaya kepimpinan partisipatif terhadap kinerja karyawan melalui motivasi kerja dan kepuasan kerja. AGORA, 5(3), 1-7. Retrieved from publicaton.petra.ac.id/index.php/manajemenbisnis/article/view/6067/5566 
Tschannen-Moran, M. (2004). Trust Matters: Leadership for Successful Schools. San Francisco, Calif, USA: Josey-Bass.

Wahab, A. A. (2011). Anatomi organisasi dan kepemimpinan pendidikan; telaah terhadap organisasi dan pengelolaan organisasi pendidikan. Bandung: Alfabeta.

Wahjosumidjo. (2010). Kepemimpinan kepala sekolah: tinjauan teoritik dan permasalahan. Jakarta: Raja Grafindo Persada.

Wahyudin. (2018). Optimalisasi peran kepala sekolah dalam implementasi kurikulum 2013. Jurnal Kependidikan, 6(2), 249-265. doi:10.24090/jk.v6i2.1932

Wening, M. H., \& Santosa, A. B. (2020). Strategi kepemimpinan kepala sekolah dalam menghadapi era digital 4.0. JMKSP Jurnal Manajemen Kepemimpinan dan Supervisi
Pendidikan), 5(1), 56-64. Retrieved from https://jurnal.univpgri-

palembang.ac.id/index.php/IMKSP/article/view/3537

Wibowo, H. N., Saleh, M., \& Effendi, R. (2020). The principal's leadership style in empowering educator in schoold. Journal of K6: Education and Management, 3(1), 1-7. Retrieved from $\underline{\text { https://j- }}$ k6em.org/index.php/ikemorg/article/view/98

Yoto. (2011). Model kepemimpinan kepala sekolah pada sekolah menengah kejuruan (sebuah kajian teoritis). Jurnal Teknik Mesin, 17(2), 1-20. Retrieved from http:training.um.ac.id/ojs/index.php/teknikmesin/article/view/3201 